\title{
Incidence of complications of trans radial access for coronary intervention
}

\author{
Iqra Hamid Khan ${ }^{1 *}$, Asif Hanif ${ }^{1}$, Tahira Ashraf ${ }^{1}$ \\ 1 University of Lahore, Lahore, Pakistan \\ *Corresponding Author: Dr. Iqra Hamid Khan, University of Lahore., Lahore, Pakistan. \\ Email: hgiqra@gmail.com
}

Received: October 17, 2020; Accepted: January 22, 2021

\section{Abstract}

Background: Common site of coronary intervention is Femoral artery due to its larger diameter and ease of puncture but it had certain complications but due to certain complications Radial approach has paved its way with the progression of better and successful coronary interventions with less complications. Objective: To check safety and observe complications from the radial approach in patients undergoing coronary intervention. Methodology: Data of 100 patients who underwent $\mathrm{PCl}$ by trans-radial approach was collected. Study included the procedural success, vascular complications, major cardiac events and other associated complications during hospitalization. After the informed consent was taken from the patient, few observations were made prior to the coronary intervention and a few complications were to be noticed peri-procedural and rest complications were observed after follow up of patient. Results: A total of 100 consecutive patients were included in the study. Mean age of patients was Mean age of the patients was $53.7 \pm 11.8$ years old. Gender distribution include $79 \%$ Male and $21 \%$ Female. $53.65+11.84$ years. Hematoma (21\%), Nausea/Vomit (31\%), Pain at site of PCI (52\%), Hand Ischemia (2\%), major bleeding (1\%) while $14 \%$ Minor bleeding and $7 \%$ Myocardial Infarction and no reported Deaths were detected from trans radial access during Percutaneous Coronary Intervention. Conclusion: Trans radial route is relatively safe and tend to have less complications than Trans femoral for $\mathrm{PCl}$. The occurrence of less complications and early mobilization of patient makes trans radial ideal approach for PCI.

Keywords: Trans radial, Complications, Coronary Intervention.

\section{INTRODUCTION}

Common site of coronary intervention is Femoral artery due to its larger diameter and ease of puncture but it had certain complications like bleeding, hematoma and delayed mobility [1$6]$.

With the progression of better and successful coronary interventions radial approach has paved the way with less complications especially when patients are taking prescribed anticoagulants, clopidogrel, aspirin and glycoprotein $\mathrm{llb} / \mathrm{llla}$ receptor inhibitors ${ }^{\text {[7-10]. }}$.

Campeau informed a success rate of $88 \%$ patients via radial approach without complications like vascular complications. It also increases the comfort of patient and less duration of stay in hospital ${ }^{[10-12]}$.

Radial approach can be associated with a few problems from puncture, hemostasis or guide management, such as hematoma, pseudoaneurysm or perforation of the artery ${ }^{[13,14]}$.
There are less number of complications observed via radial approach like bleeding bleeding, hematoma, nausea/vomiting, hand ischemia and revascularization. The use of non-surgical intervention is quite frequent.

Bleeding from the puncture site represents a leading concern after coronary stenting, sometimes it may be life-threatening and usually it prolongs the hospital stay. To prevent bleeding complications from the puncture site, the radial artery has been increasingly chosen as the route of choice for transradial approach $[15,16]$.

\section{OBJECTIVE}

The aim of this study was to check safety and observe complications from the radial approach in patients undergoing coronary intervention. 


\section{MATERIAL \& METHODOLOGY}

\section{Study Design}

It was a cross sectional descriptive study.

\section{Settings}

The survey was conducted in Gulab Devi Chest Hospital, Lahore

Sampling Technique: Simple Random sampling was used. The data was collected from patients who underwent trans-radial access for coronary intervention after Myocardial Infarction.

\section{Methodology:}

Data of 100 patients who underwent $\mathrm{PCl}$ by trans-radial approach was collected. Study included the procedural success, vascular complications, major cardiac events and other associated complications during hospitalization.

After the informed consent was taken from the patient, few observations were made prior to the coronary intervention and a few complications were to be noticed peri procedural and rest complications were observed after follow up of patient.

\section{RESULTS}

Mean age of the patients was $53.65 \pm 11.844$ years. Gender distribution include $79 \%$ Male and $21 \%$ Female. Procedural success was achieved in $100 \%$ cases. Multivessel Percutaneous Coronary Intervention was done in $100 \%$ patients. Maximum Targeted lesions treated were associated with LAD (69.61\%), RCA (42.22\%), followed by LCX $(33.72 \%)$ and LMS (3.17\%). Associated Risk factors of the patients included hypertension 39\%, Diabetic were 33\%, Renal insufficiency 4\%, Smoking 34\%, Family history for Myocardial Infarction 47\& and Obesity in $11 \%$. There was no significant association observed between the risk factors and access to trans radial site as $\mathrm{P}>0.005$.

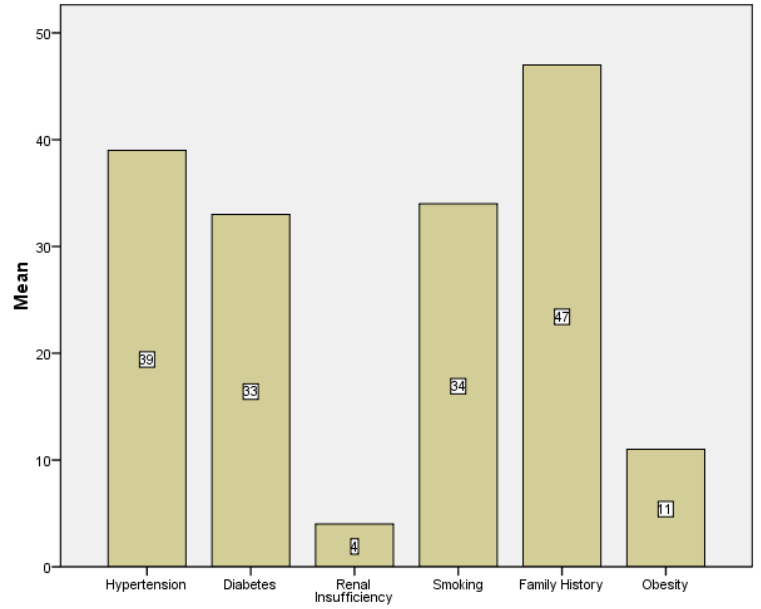

Figure 1: Associated Risk factors of the patients

No case of vascular complications such as dissection, vascular perforation, radial artery occlusion were observed. Whereas, Hematoma or Bruising was observed in 21 patients, 31 Patients had nausea/vomiting. 52 patients had radial site pain after 24 hours of procedure, 2 patient presented with Hand Ischemia, 14 cases of minor bleeding were observed whereas, only 1 case of major bleeding. There were periprocedural myocardial infarctions observed in 7 patients and No deaths reported (Table 1).

Table 1: Complications and Occurrence

\begin{tabular}{|l|l|}
\hline Complications & Occurrence \\
\hline Hematoma/Bruising & 21 \\
\hline Nausea/Vomit & 31 \\
\hline Radial site Pain & 52 \\
\hline Hand Ischemia & 2 \\
\hline Major Bleeding & 1 \\
\hline Minor Bleeding & 14 \\
\hline Ml & 7 \\
\hline Deaths & 0 \\
\hline
\end{tabular}

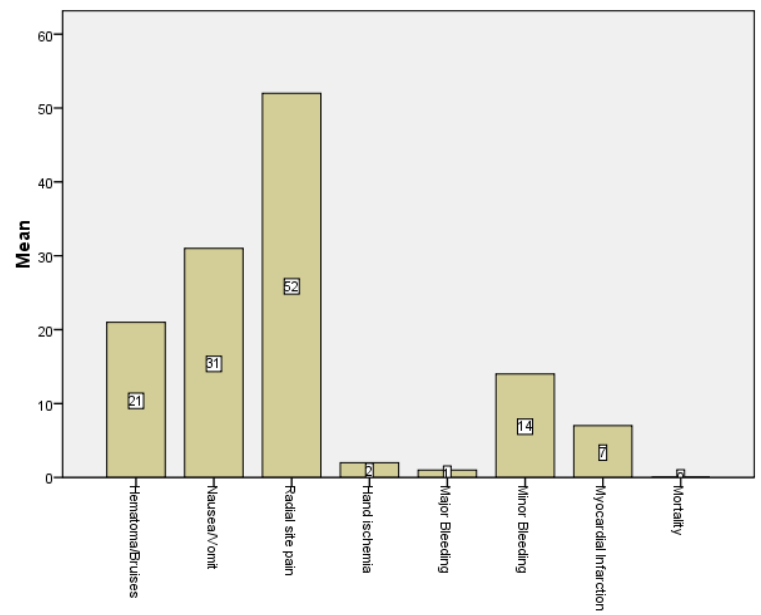

Figure 2: Graphical representation of the Complications and Occurrence in patients

\section{DISCUSSIONS}

Radial site comparatively offers a safer route regarding complications like another study conducted in order to access neurological complications [17], hematoma or spasm $\left[{ }^{18]}\right.$. Hematoma was encountered frequently in $0.38 \%$ patients in another study ${ }^{[19]}$ showing less incidence to this study.

No severe vascular complications like perforation, dissection or even occlusion were observed unlike [20,21] attributed reason was prolonged increased pressure compression on the radial artery but in this study additionally, a few minor complications like radial site pain in almost half of the study patients, nausea/vomit in 21 patients, hand ischemia in 2 patient was observed that may have occurred due to prolong cannulation or probably patient had prior history for Raynaud's disease that was kept uninformed thou its incidence is comparatively very rare among other studies ${ }^{[22]}$. Minor Bleeding may not be life threatening that is evident in radial access while femoral bleeding really can worsen due to high pressure of femoral artery that may later require blood transfusion [21].

There was reduction in major bleeding, shock corresponding trend for reduction in $\mathrm{Ml}$ or deaths in this study and similar results 
were found in Jolly et al study ${ }^{[23]}$.

Cardiac biomarkers (CK-MB) were determined to figure out the ratio of infarction during $\mathrm{PCl}$ which revealed $7 \%$ patients approximately like other studies $[24,25,26,27]$ that may be sue to diffuse vessel intervention or involving Left Main stem.

\section{CONCLUSION}

Trans radial route is relatively safe and tend to have less complications than Trans femoral for PCI. The occurrence of less complications and early mobilization of patient makes trans radial ideal approach for $\mathrm{PCI}$.

\section{REFRENCES}

1. Chodór P, Krupa H, Kurek T, Sokal A, Swierad M, Was T, et al. RADlal versus femoral approach for percutaneous coronary interventions in patients with Acute Myocardial Infarction (RADIAMI): a prospective, randomized, single-center clinical trial. Cardiol J. 2009; 16(4):332-40.

2. Shah SFA, Hadi A, Shah I, Jan H, Gul AM, Irfan M, et al. Utility of transradial coronary angioplasty in patients with chronic stable angina discharged on same day. Journal of Postgraduate Medical Institute (Peshawar-Pakistan). 2012; 26(2).

3. Hetherington SL, Adam Z, Morley R, de Belder MA, Hall JA, Muir $\mathrm{DF}$, et al. Primary percutaneous coronary intervention for acute ST-segment elevation myocardial infarction: changing patterns of vascular access, radial versus femoral artery. Heart. 2009; 95(19):1612-8.

4. Rao SV, Ou F-S, Wang TY, Roe MT, Brindis R, Rumsfeld JS, et al. Trends in the prevalence and outcomes of radial and femoral approaches to percutaneous coronary intervention: a report from the National Cardiovascular Data Registry. JACC: Cardiovascular Interventions. 2008; 1(4):379-86.

5. Fukuda N, Iwahara S-i, Harada A, Yokoyama S, Akutsu K, Takano $M$, et al. Vasospasms of the radial artery after the transradial approach for coronary angiography and angioplasty. Japanese heart journal. 2004; 45(5):723-31.

6. Ruzsa Z, Ungi I, Horváth T, Sepp R, Zimmermann Z, Thury A, et al. Five-year experience with transradial coronary angioplasty in ST-segment-elevation myocardial infarction. Cardiovascular Revascularization Medicine. 2009; 10(2):73-9.

7. Cruden NL, Teh $\mathrm{CH}$, Starkey IR, Newby DE. Reduced vascular complications and length of stay with transradial rescue angioplasty for acute myocardial infarction. Catheterization and cardiovascular interventions. 2007; 70(5):670-5.

8. Bagger H, Kristensen JH, Christensen PD, Klausen IC. Routine transradial coronary angiography in unselected patients. The Journal of invasive cardiology. 2005; 17(3):139-41.

9. Amoroso G, Limbruno U, Petronio AS, Ferrali E, Ciabatti N, De Carlo M, et al. Safety, feasibility, and six-month outcomes of a systematic strategy of direct coronary stenting by a transradial approach in patients with single-vessel disease. ITALIAN HEART JOURNAL. 2004; 5:22-8.

10. Zankl A, Andrassy M, Volz C, Ivandic B, Krumsdorf $U$, Katus $\mathrm{H}$, et al. Radial artery thrombosis following transradial coronary angiography: incidence and rationale for treatment of symptomatic patients with low-molecular-weight heparins. Clinical Research in Cardiology. 2010; 99(12):841-7.

11. Campeau L. Percutaneous radial artery approach for coronary angiography. Catheterization and cardiovascular diagnosis. 1989; 16(1):3-7.

12. Jan H, Hadi A, Fahim M, Gul AM, Irfan M, Khan SB, et al. Radial artery approach for coronary intervention-early experience. Pakistan Heart Journal. 2012; 45(1).

13. Fagih B, Beaudry Y. Pseudoaneurysm: a late complication of the transradial approach after coronary angiography. The Journal of invasive cardiology. 2000; 12(4):216-7.

14. Saito S, Ikei H, Hosokawa G, Tanaka S. Influence of the ratio between radial artery inner diameter and sheath outer diameter on radial artery flow after transradial coronary intervention. Catheterization and Cardiovascular Interventions. 1999; 46(2):173-8.
15. Kiemeneij F, Laarman GJ, Odekerken D, Slagboom T, van der Wieken R. A randomized comparison of percutaneous transluminal coronary angioplasty by the radial, brachial and femoral approaches: the access study. Journal of the American College of Cardiology. 1997; 29(6):1269-75.

16. Choussat R, Black A, Bossi I, Fajadet J, Marco J. Vascular complications and clinical outcome after coronary angioplasty with platelet IIb/IIla receptor blockade. Comparison of transradial vs transfemoral arterial access. European heart journal. 2000; 21(8):662-7.

17. Ratib K, Mamas MA, Routledge HC, Ludman PF, Fraser D, Nolan $\mathrm{J}$. Influence of access site choice on incidence of neurologic complications after percutaneous coronary intervention. American heart journal. 2013; 165(3):317-24.

18. Jia D-a, Zhou Y-j, Shi D-m, Liu Y-y, Wang J-I, Liu X-I, et al. Incidence and predictors of radial artery spasm during transradial coronary angiography and intervention. Chinese medical journal. 2010; 123(7):843-7.

19. Sanmartín M, Cuevas D, Goicolea J, Ruiz-Salmerón R, Gómez M, Argibay V. Vascular complications associated with radial artery access for cardiac catheterization. Revista Española de Cardiología (English Edition). 2004; 57(6):581-4.

20. Tuncez A, Kaya Z, Aras D, Yıldız A, Gül EE, Tekinalp M, et al. Incidence and predictors of radial artery occlusion associated transradial catheterization. International journal of medical sciences. 2013; 10(12):1715.

21. Doyle BJ, Ting HH, Bell MR, Lennon RJ, Mathew V, Singh M, et al. Major femoral bleeding complications after percutaneous coronary intervention: incidence, predictors, and impact on longterm survival among 17,901 patients treated at the Mayo Clinic from 1994 to 2005. JACC: Cardiovascular Interventions. 2008; 1(2):202-9.

22. Kanei Y, Kwan T, Nakra NC, Liou M, Huang Y, Vales LL, et al. Transradial cardiac catheterization: a review of access site complications. Catheterization and Cardiovascular Interventions. 2011; 78(6):840-6.

23. Jolly SS, Amlani S, Hamon M, Yusuf S, Mehta SR. Radial versus femoral access for coronary angiography or intervention and the impact on major bleeding and ischemic events: a systematic review and meta-analysis of randomized trials. American heart journal. 2009; 157(1):132-40.

24. Dangas G, Mehran R, Feldman D, Stoyioglou A, Pichard AD, Kent $\mathrm{KM}$, et al. Postprocedure creatine kinase-MB elevation and baseline left ventricular dysfunction predict one-year mortality after percutaneous coronary intervention. The American journal of cardiology. 2002; 89(5):586-9.

25. Stone GW, Mehran R, Dangas G, Lansky AJ, Kornowski R, Leon MB. Differential impact on survival of electrocardiographic $Q$-wave versus enzymatic myocardial infarction after percutaneous intervention. Circulation. 2001; 104(6):642-7.

26. Andron M, Stables RH, Egred M, Alahmar AE, Shaw MA, Roberts $\mathrm{E}$, et al. Impact of periprocedural creatine kinase-MB isoenzyme release on long-term mortality in contemporary percutaneous coronary intervention. The Journal of invasive cardiology. 2008; 20(3):108-12.

27. Riaz A, Hanif MI, Khan IH, Hanif A. Frequency and causes of periprocedural myocardial infarction in complex coronary interventions. Pakistan heart journal. 2019; 52(2). 